\title{
Medico Legal Cases in One Stop Crisis Management Center (OCMC) Kaski
}

Madan Prasad Baral

\section{Correspondence:}

Dr. Madan Prasad Baral, MBBS,MD

Department of Forensic Medicine

Pokhara Academy of Health Sciences

Western Regional Hospital,Pokhara

Email: madanprasadbaral@gmail.com

Article received : $5^{\text {th }}$ December, 2018

Article accepted : $1^{\text {st }}$ July, 2019

\section{ABSTRACT}

Background:The OCMC (One stop crisis management center) has been established in the recognizedgovernment hospitals of Nepal. The OCMC has builtcoalition and create an organizational management system with other organizations for providing comprehensive health and treatment services, legal aid services, and counseling services and make certain protection to the survivors of GBV (Gender based violence) as well as to manage and control GBV incident. Worldwide more than 119 countries have laws on domestic violence, 125 countries have laws on sexual pestering and 52 countries have laws on marital rape but still women are suffering from different physical, sexual and Psychological violence. Rape, hurt/battery, Indecent assault, are the main forms of violence.

Materials and Methods:Study is conducted in Western regional Hospital Pokhara, in OCMC (One stop crisis management center).It is a cross-sectional type of study. Data collected by the observation, interview and case study from the survivors of violence, available published materials related to women Violence and OCMC are also studied. Total 200 cases of GBV survivors came to OCMC center of Kaski from 2073Baisakh to 2074Ashad and included in the study as a primary source of data. Conclusion and Result:Out of total 200 cases, sexual offence victims were maximum in number which was 140 and least were forced marriage victim which were only 4 in number. More than $50 \%$ of dalit caste people were the survivors of GBV cases. GBV cases were predominant in age group of 2030 years. Maximum numbers of victims of GBV in sexual offence cases were alleged Rape cases which accounts $85 \%$ of total cases came to OCMC center. Key Words: One Stop Crisis Management Center, OCMC, Gender Based Violence, GBV, Medico legal case, sexual offence.

not fact that men are not violated in society but through various studies it is found that in compare to Female, male are very less violated. Women are always not pursuing their full right due to society barrier in all sectors from home to work place. Throughout the world 1 in $3(35 \%)$ female experience some kind of physical and/or sexual violence by a partner or sexual violence always exchangeable to women violence. This is 
by a non-partner. $30 \%$ the women reported that they have suffered from physical and/or sexual violence intimate life partner. ${ }^{1}$ Through the study of different countries only less than $40 \%$ of women suffering from violence are seeking some kind of help. ${ }^{2}$ This study makes an attempt to study the OCMC Program and its effect for the survivor as well as medico legal cases as a case of GBV. Government of Nepal have OCMC program in different regions of the country under the hospital. The number of the women violence problem is rising in the country. The increasing problem of the women violence should be recognized from the policy perspectives. Government is spending the huge resource and effort to address the violence against women, but still some gap is seen between the government effort and survivors of violence. The effort of the government in OCMC Program can be justified only when it achieve the objective that has been set by the government. Worldwide more than 119 countries have laws on domestic violence, 125 have laws on sexual harassment and 52 have laws on marital rape and many more normative framework to address violence against women despite these still women are suffering from different physical, sexual and Psychological violence. Rape $^{3}$, hurt/battery ${ }^{4}$, Indecent assault ${ }^{5}$ are the main forms of violence. Studies in Nepal have documented the prevalence of sexual violence in women from $12 \%$ to $50 \% .^{6-9}$ Empirical studies in Nepal ${ }^{10}$ have shown that among women 15 to 49 years of age, $22 \%$ had experienced physical violence and $12 \%$ had experienced sexual violence at least once in their lives. Sexual Violence Assessment in Seven Districts of Nepal study drew attention to adolescent girls: 1 in $10(9.8 \%)$ girls $15-19$ years of age reportedly experienced sexual violence. ${ }^{11}$ In today context women against violence is globally discuss issue and different initiation are done from government and non-government to address this issue. A large literature exists on caring for survivors of physical and sexual abuse within specific professional disciplines, but research on the effectiveness, quality and impact of social service programs is scarce in low and middleincome countries. Most evaluations document numbers of persons served, services provided, and types of cases reported. ${ }^{12}$ However, Studies in Nepal have documented the prevalence of sexual violence in women from $12 \%$ to $50 \% \cdot{ }^{13}$ Nepali women from claiming reproductive age have secondary suicide aerial attacker rates, large portions of which would attributed with DV toward life partner alternately family-members. ${ }^{14}$ Colombini, Manuela, et al (2011) the review done on one stop crisis center focuses The discoveries demonstrate that women's NGOs and Health Professional were instrumental in the detailing and scaling-up of the OSCC approach. Be that as it may, the resulting breakdown of the NGO-wellbeing coalition adversely affected on the long term execution of the implementation, which needed money finical resources and clear strategy direction from the Ministry of Health. The discoveries affirm that a plainly characterized organization amongst NGOs and health professional staff can be capable for affecting the lawful and implementation condition in which medicinal services administrations for intimate partner violence are produced. ${ }^{15}$

\section{MATERIALS AND METHODS}

Researcher did the study in Kaski district as researcher belongs to Kaski district and currently working in Western Regional Hospital as a Medical Officer (Forensic) and member of OCMC(One stop crisis management center) as well as Coordinator of case management committee of OCMC center. This is a cross-sectional study which was conducted in OCMC center, Western regional Hospital Pokhara, Nepal on 200 cases of Gender based violence (GBV).It is conducted during the period of 2073 Baisakh to 2074 Ashad.Necessary other data collected from the available published materials related to women Violence and OCMC, GBV survivors came to OCMC center of Kaski. The quantitative data was analyzed by using descriptive statistics and presented in relevant tables, with frequencies and percentages. The nature of the study is exploratory where Researcher had tried to find out detailed perception of service user (victims of GBV) about reflecting the effectiveness of OCMC in addressing Gender based violence through case studies and the detail information regarding the factors which influence the OCMC.

\section{RESULT}

Total numbers of GBV survivor cases presented in OCMC center of Kaski district in a time period of 2073 Baisakh to 2074 Ashad were 200.All were medicolegal cases.Among them 140 was sexual assault victims amounting $70 \%$ of total cases and then 36 cases were of Domestic violence cases 
amounting $18 \%$ of total percentage. 20 cases were of Physical assault cases amounting $10 \%$ of total cases. Similarly 4 cases were of force marriage cases amounting $8 \%$ of total cases presented in OCMC center Kaski.

Table 1: Total Medicolegal cases in OCMC center, Kaski, Western Regional Hospital

\begin{tabular}{|l|l|l|}
\hline Type of GBV cases & $\begin{array}{l}\text { Number } \\
\text { of cases }\end{array}$ & $\begin{array}{l}\text { Percentage } \\
\text { of cases }\end{array}$ \\
\hline Sexual offence victims & 140 & $70 \%$ \\
\hline $\begin{array}{l}\text { Domestic violence } \\
\text { victims }\end{array}$ & 36 & $18 \%$ \\
\hline Physical assault cases & 20 & $10 \%$ \\
\hline Force Marriage cases & 4 & $8 \%$ \\
\hline Total & 200 & $100 \%$ \\
\hline
\end{tabular}

Out of 200 total cases of sexual offence cases 170 were of Alleged Rape case which were $85 \%$ of total cases. Among those $10 \%$ of cases are of sodomy cases which amounts $10 \%$ of total cases. Likewise $5 \%$ of cases are of child abuse cases which amounts 10 numbers of cases out of total 200 cases.

Table 2: Different types of medico legal case as a sexual offence cases

\begin{tabular}{|l|l|l|}
\hline $\begin{array}{l}\text { Name of different } \\
\text { type of cases }\end{array}$ & $\begin{array}{l}\text { Number of } \\
\text { cases }\end{array}$ & $\begin{array}{l}\text { Percentage } \\
\text { of cases }\end{array}$ \\
\hline Alleged Rape & 170 & $85 \%$ \\
\hline Sodomy & 20 & $10 \%$ \\
\hline Child abuse & 10 & $5 \%$ \\
\hline $\begin{array}{l}\text { Total number of } \\
\text { cases }\end{array}$ & 200 & $100 \%$ \\
\hline
\end{tabular}

Domestic violence cases were 36 in number out of total 200 cases. Various types of domestic violence cases includes Assaulted by husband cases which were 30 in number out of total 36cases with percentage of 88.88 percentage. After this second most type of domestic violence case was assaulted by mother in law case in which $5.55 \%$ of total cases were included and just 2 in number out of total 34 cases. Third most type of domestic violence case was assaulted by a father in law case which accounts only one case out of total 36 cases and amounts only 2.77 percentages. Third most type of domestic violence case was similar to the case of assaulted by sister of husband which amounts $2.77 \%$ and 1 case only.

Table: 3 Different types of medico legal cases as a Domestic violence cases

\begin{tabular}{|l|l|l|}
\hline $\begin{array}{l}\text { Name of different } \\
\text { type of domestic } \\
\text { violence }\end{array}$ & $\begin{array}{l}\text { Number of } \\
\text { cases }\end{array}$ & $\begin{array}{l}\text { Percentage } \\
\text { of cases }\end{array}$ \\
\hline $\begin{array}{l}\text { Assaulted by } \\
\text { Husband }\end{array}$ & 32 & $88.88 \%$ \\
\hline $\begin{array}{l}\text { Assaulted by mother } \\
\text { in law }\end{array}$ & 2 & $5.55 \%$ \\
\hline $\begin{array}{l}\text { Assaulted by father } \\
\text { in law }\end{array}$ & 1 & $2.77 \%$ \\
\hline $\begin{array}{l}\text { Assaulted by sister of } \\
\text { husband }\end{array}$ & 1 & $2.77 \%$ \\
\hline Total & 36 cases & $100 \%$ \\
\hline
\end{tabular}

In a physical assault cases 20 cases were presented out of 200 cases of GBV survivors. Among which assaulted by wife were of 15 cases out of total 20 cases of physical assault and which amounts $75 \%$ cases out of 100 . Then second highest number of physical assault cases was assault by brother of husband for property matter which amounts only 3 cases out of 20 that is only $15 \%$ of total physical assault cases. Next one is assaulted by unknown person and reveals only $10 \%$ of total physical assault cases amounting only 2 cases out of total 20 cases of physical assault.

\section{Table: 4 Different types of medico legal cases as a Physical assault cases}

\begin{tabular}{|l|l|l|}
\hline $\begin{array}{l}\text { Name of different } \\
\text { type of physical } \\
\text { assault }\end{array}$ & $\begin{array}{l}\text { Number of } \\
\text { cases }\end{array}$ & $\begin{array}{l}\text { Percentage } \\
\text { of cases }\end{array}$ \\
\hline Assaulted by wife & 15 & $75 \%$ \\
\hline $\begin{array}{l}\text { Assaulted by Brother } \\
\text { of husband for } \\
\text { property }\end{array}$ & 3 & $15 \%$ \\
\hline Unknown & 2 & $10 \%$ \\
\hline Total & 20 cases & $100 \%$ \\
\hline
\end{tabular}

There was predominance of 20-30 years age group which was 150 in number and 75 in percentage. This was followed by a age group of 40-50 years age group in which 20 cases were the victims accounting 10 percentage of total cases. Then in a age group of 30-40 years 18 victims of GBV took benefit in OCMC center measures 9 percentage of 
total cases presented in OCMC center. Lastly age groups of 10-20 years were presented in OCMC center which accounts only 6 percentages of total cases.

Table: 5 Age wise distribution of total cases

\begin{tabular}{|l|l|l|}
\hline Age range & Number of cases & Percentage \\
\hline $10-20$ years & 12 & $6 \%$ \\
\hline $20-30$ years & 150 & $75 \%$ \\
\hline $30-40$ years & 18 & $9 \%$ \\
\hline $40-50$ years & 20 & $10 \%$ \\
\hline
\end{tabular}

The highest number of victims of gender based violence(GBV) presented in OCMC (One stop crisis management center) of Kaski district were belongs to Dalit caste which were 110 in number out of 200 cases.It accounts 55 Percentage of total cases. It was followed by Chhetri and Gurung of 25 persons in each caste amounts $12.5 \%$ each. Then it was immediately followed by Magar caste which accounts 16 victims and 8 percentage of total cases. Newar caste people presented were only14 in number and least was Bramhins of only 10 cases.

\section{Table: 6 Caste wise distribution of total cases}

\begin{tabular}{|l|l|l|}
\hline Caste & Number of cases & Percentage \\
\hline Bramhins & 10 & $5 \%$ \\
\hline Chhetris & 25 & $12.5 \%$ \\
\hline Newars & 14 & $7 \%$ \\
\hline Gurungs & 25 & $12.5 \%$ \\
\hline Magars & 16 & $8 \%$ \\
\hline Dalits & 110 & $55 \%$ \\
\hline
\end{tabular}

\section{DISCUSSION}

OCMC cases in 14months period at Kaski District OCMC center (Western Regional Hospital) were 200 cases and all of the OCMC cases got benefited from the OCMC program conducted in Kaski district. Most of the cases were directly brought by police after FIR in police station. In all 200 cases lawyer of district attorney office were presented as per need during the OCMC case examination. All data were collected by a author. Most common method used by a author for collecting the data was interviewing the GBV victims (survivors) presenting in a Hospital based OCMC center present in Western Regional Hospital, Pokhara. Besides this interview with a staffs working in OCMC center, related NGOs and INGOs were also done for data collection. Most of the data collected and presented here were in the tabular form which was interpreted by suitable figures. Main source for data collection was OCMC case study by interview during examination. Sexual offence cases were the highest number of cases presented in OCMC center which was directly related to GBV and in which mostly women and children were the victims. Force marriage cases were the least number of cases presented to OCMC center in which teenage girls were the main victims including few number of children as well. Although Domestic violence cases and Physical assault cases were similar types of cases but in this research work researcher had included both in separate topics in data presentation because as in GBV cases both male and females were dealt. Here in this report in physical assault cases assaulted by wife cases were also included that's why physical assault cases and domestic violence cases were dealt separately. In domestic violence cases wives were assaulted by husbands and other relatives. Maximum numbers of cases presented in OCMC center were fall in an age group of 20-30 years and the maximum numbers of cases were belongs to dalit caste community. Awareness in this age group and in that community will decrease the number of cases presenting to OCMC center of kaski district in future.

\section{CONCLUSION}

The Gender Based violence (GBV) is always interchangeable to women violence. Throughout the world 1 in $3(35 \%)$ experience some kind of physical and/or sexual violence by a partner or sexual violence by a non-partner. $30 \%$ the women reported that they have suffered from physical and/or sexual violence intimate life partner. Nepal is also seeing in providing the multi-dimensional service to survivor in order to address women violence. In that context OCMC(One stop crisis management center) is another form of the service to the women suffering from any kind of violence in Nepal. The service is provided by the Hospital based one stop crisis management center.Out of total 200 cases sexual offence victims were maximum in number which was 140 and least were forced marriage victim which were only 4 in number.In domestic violence cases assaulted by the husband cases were more in number accounts to 32 out of 36 cases.Dalit caste people were the main victims of GBV cases. More than $50 \%$ of dalit caste people were the survivors of GBV cases.GBV cases were predominant in age group of 20-30 years.Maximum numbers of victims of GBV in sexual offence cases were Rape cases which accounts $85 \%$ of total cases came to OCMC center.In sexual offence cases, child abuse cases were very less in number that was only 
10 out of 200 cases in Western Regional Hospital, pokhara.

\section{RECOMMENDATIONS}

It is recommended that the GBV victims were not easy to identify.Hospital based OCMC program helps to identify and help the GBV survivors in the community.In present study GBV survivors came to OCMC center were maximum of the age group of 20-30 years of age so it is recommended that to provide the maximum knowledge about GBV, consequences and outcomes of GBV in society (community).Educating the age group of 20-30 years in Kaski district will be fruitful to reduce the number of GBV cases presenting to OCMC. This study also showed that the Dalit caste people were the main victims of GBV cases so it is recommended that awareness and education program about the consequences of GBV in Dalit community of Kaski district will help to reduce the number of cases of GBV coming to OCMC center in Kaski.Most of the GBV survivors and even common people living in kaski district were not familiar about OCMC program so it is recommended to do advertisement about the OCMC program by various types of media in national level and local level present in kaski district. As like in kaski district this type of OCMC program will be helpful in all districts of Nepal for GBV survivors. The data was collected and processed before 2074 Bhadra so the latest law is not coded in the study reference. This change in law affect the study reference and may not compatible in few points with current law.

\section{REFERENCES}

1.World Health Organization, 2016. Global and regional estimates of violence against women: prevalence and health effects of intimate partner violence and non-partner sexual violence

2.United Nations Economic and Social Affairs (2015). The World's Women 2015, Trends and Statistics, p.159.

3.Muluki ain-general code with latest amendment 2068, Part-4, chapter 14, On rape, number 1.

4.Muluki ain-general code with latest amendment 2068, Part-4, chapter 9, Hurt/ battery ,number 1and 2

5.Muluki ain-general code with latest amendment 2068, Part-4, chapter 13, On intension of sex, number 1

6. SAATHI, The Asia Foundation. 1997. A situation- al analysis of violence against women and girls in Nepal. Online Library: Addressing Child Trafficking website. http://www.childtrafficking.com/Docs/ situation_analysis_violence_womenngirls_070402. pdf.

7. Women's Rehabilitation Centre (WOREC): Breaking the Silence: Needs Identification of Victims of Gender-based Violence. Kathmandu, Nepal 2002

8. Deuba AR, Sana PS, SAMANATA, et al. 2005. A Study on Linkage between Domestic Violence and Pregnancy. Kathmandu: SAMANTA-Institute for Social and Gender Equity

9. Puri M, Forst M, Tamang J, et al.. The prevalence and determinants of sexual violence against young married women by husbands in rural Nepal. BMC Research Notes.2012; 5(1):291

10. Nepal Ministry of Health and Population, New ERA, ICF International. 2012. Nepal demographic and health survey 2011. DHS Program website. http://dhsprogram.com/pubs/pdf/FR257/ FR257\%5B13April2012\%5D.pdf.

11. Himalayan Human Rights Monitors/PPCC, Enabling State Programme (ESP/DFID). 2012. Sexual violence assessment in seven districts in Nepal: A study conducted in Kanchanpur, Kailali, Bardiya, Banke, Dang, Parsa, and Bara. Himalayan Human Rights website. http://www.himrights.org/download/12 1633811810.pdf.

12. Brignall, S. and Modell, S., An institutional perspective on performance measurement and management in the 'new public sector'. Management accounting research, 2000;11(3), p.281-306

13. Puri M, Forst M, Tamang J, et al.The prevalence and determinants of sexual violence against young married women by husbands in rural Nepal. BMC Research Notes. 2012.5(1):291.

14. Joshi SK..Violence against Women (VAW) in Nepal: Role of health care workers.Kathmandu University Medical Journal.2009;7: p89-91

15. Colombini, M., Ali, S.H., Watts, C. and Mayhew, S.H.,. One stop crisis centres: A policy analysis of the Malaysian response to intimate partner violence. Health research policy and systems, 2011; 9(1), p.25. 